\title{
Influence of Different Levels of Crude Protein and Metabolizable Energy on Production Performance of Ross Broiler
}

\author{
Alfred S. Karomy Hassan Nima Habib* Salwan A. Kasim \\ Department animal science, College of Agriculture, University of Basrah, Iraq
}

\begin{abstract}
The objective of this study was to estimate the suitability of recommending Ross guide requirements of crude protein (C.P) and metabolizable energy (M.E) during the starter and finisher stages as compared with low and high amount of these nutrients at basrah region. Four treatment with three of 15 ROSS broiler chicks per replicated were used. The treatment were fed diets 1, 2, 3 and 4 which were contented 22, $23 \%$ C.P (as ross guide recommended), (24, 25) \% C.P and 2864, $2990 \mathrm{Kcal} \mathrm{M.E/kg} \mathrm{(as} \mathrm{Ross} \mathrm{guide),} \mathrm{(3120} \mathrm{and} \mathrm{3207)} \mathrm{Kcal} \mathrm{M.E/kg} \mathrm{diets}$ respectively for the starter and 18, 19 \% C.P (as Ross guide), 20, 21 \% C.P and 2886, $3041 \mathrm{Kcal} \mathrm{M.E/kg} \mathrm{(as} \mathrm{Ross}$ guide), $(3204,3357) \mathrm{Kcal}$ M.E/kg diet for the finisher period respectively, The ratio between M.E and C.P in these diets treatments were equal to 130 the starter diets and 160 to the finisher diets. Live body weight, weight gain, feed consumption, C.P and M.E consumption, production index, dressing percentage, thigh and Brest percentage high significantly $(\mathrm{p}<0.05)$ and low in the feed conversation ratio, abdominal fat and the gizzared percentage were reputed in treatment 3 as compared with treatments 1, 2 and 4 it can be concluded that diet contented Ross guide requirement of C.P and M.E were not fit enough of these nutrients to give better performance in basrah region.
\end{abstract}

DOI: $10.7176 / \mathrm{JBAH} / 9-18-04$

Publication date:September $30^{\text {th }} 2019$

\section{Introduction}

Nutrition is one of the parameters that broiler chick producers have the most influence. The two main nutrients in most livestock diets are energy and protein, it is cost about $90 \%$ of the total cost which should be utilized most efficiently for desired economy of production and formulation of poultry ration (Durunna et al ., 2005). Energy and protein are very important nutrients for broiler. Energy is required for body function and protein is essential constituent of all tissues of bird's body. Protein having major effect on growth performance of the birds is the most expensive nutrient in the broiler diets (Kamran et al., 2004).

Current commercial hybrids with high performance require suitable energy and protein diets which would enable the maximum exploitation of these genetic potential, the nutrient requirements of broiler chicken depend on its stage of growth (FAO, 2003).

Several workers have chosen to express these nutrient requirements in terms of energy and protein ratios. The energy and protein studies have been conducted with chicks by Rahimi and Hassanzadeh (2007) and Dairo et al. (2010). In poultry industry the regime of dietary energy and protein were established both in the tropics and temperature climate (NRC, 1994; Ojewaia and longe, 1999). The performance of broiler were evaluated by Olomu and Offioncy (1980) who reported that $23 \%$ protein with either 2800 or $3000 \mathrm{Kcal} / \mathrm{Kg}$ metabolizable energy and the ratio were 121.7 and 130.43 receptivity which adequate to the requirement for broiler starters. However, research evaluating the performance of commercial broiler chicks fed diets different in protein and energy lack. Therefore, this study evaluated the performance of broiler chicken fed diets containing different combinations of energy and protein to Ross hybrid at basrah region

\section{Martials and methods}

An experiment was conducted at poultry research unit, animal production department, college of agriculture, university of basrah from $15 / 11 / 2018$ to $20 / 12 / 2018$. A total of 180 day-old Ross chicken were randomly divided into four treatment groups with three replicates of 15 chicks per replicate totally us per treatment initial weight was 36 gm per chick. The chicks were reared in twelve $1 \times 1.5 \mathrm{~m}$ cages to 35 days.

The brooding temperature was kept at $32 \mathrm{c}^{\circ}$ during the first week and then was gradually decreased by $2 \mathrm{c}^{\circ}$ each week. 24 hours light was provided in the rearing house during the experimental period.

The dietary treatments were in arrangement with four crude protein levels and four metabolizable energy levels as shown in table 1 and 2 . The treatment combination were as follows: 
Table1:Composition of the broiler starter and finisher experimental diets

\begin{tabular}{|l|l|l|l|l|l|l|l|l|}
\hline \multirow{2}{*}{ Ingredients (\%) } & \multicolumn{6}{l}{ Starter phase 0 - 21 days } & \multicolumn{4}{l|}{ Finisher phase 22-35 days } \\
\cline { 2 - 11 } & T1 & T2 & T3 & T4 & T1 & T2 & T3 & T4 \\
\hline Corn & 43 & 43 & 43 & 43 & 63 & 65 & 63 & 57.7 \\
\hline Soybean meal & 29 & 31.7 & 35.3 & 39 & 21 & 23 & 26 & 29 \\
\hline Concentrate protein 40 \% & 5 & 5 & 5 & 5 & 5 & 5 & 5 & 5 \\
\hline wheat & 15.5 & 15.5 & 10.5 & 4 & - & - & - & - \\
\hline Oyster shell & 2 & 2 & 2 & 2 & 1.5 & 1.5 & 1.5 & 1.5 \\
\hline Sunflower oil & 0.5 & 1.5 & 4 & 6.5 & 1 & 1.6 & 3.7 & 6.6 \\
\hline Wheat bran & 3 & 1.1 & - & - & 3 & 2 & - & - \\
\hline sawdust & 1.8 & - & - & - & 5.3 & 1.7 & 0.6 & - \\
\hline Vitamins and minerals premix & 0.2 & 0.2 & 0.2 & 0.2 & 0.2 & 0.2 & 0.2 & 0.2 \\
\hline \multicolumn{7}{|l|}{ Determined analysis } \\
\hline Crude protein & 22.01 & 23.00 & 23.99 & 24.98 & 18.07 & 19.06 & 20.03 & 21.00 \\
\hline M.E/kg & 2864 & 2990 & 3120 & 3247 & 2886 & 3041 & 3204 & 3357 \\
\hline Calories: protein ratio & 130 & 130 & 130 & 129.9 & 159.7 & 159.5 & 159.9 & 159.8 \\
\hline
\end{tabular}

Live body weight, weight gain, feed consumption, feed conversion ratio (FCR) and production index was calculated according to the equation of Naji, (2006)

At the end of 35 day six bird ( 3 female and 3 male) were taken to slaughters; dressing percentage were calculated and relation weight for thigh, Brest, liver, heart, gizzard, proventriculus and the abdominal fat, the amount of crude protein and metabolizable energy consumption by each birds was calculated by the following equation

Crude protein consumption $=\frac{\text { feedintak }(g) \times \% \text { C.P }}{100}$

Metabolisable energy $=\frac{\text { feedintak }(\mathrm{g}) \times \mathrm{kcal} / \mathrm{g}}{100}$

Completely randomized design (CRD) way used to study the effect of difference treatment in all traits, The differences between the averages were also tested using the least significant difference (L.S.D) using the SPSS (2009)

\section{Result}

The date of weekly body weight and weight gain were presented in table 2 and 3 which reveal significantly differences $(p<0.05)$ during all weeks of the experiment. The highest live weight and weight gain during all the experimental weeks were obtained by the birds fed diet $3(1723,1685) \mathrm{g}$ whereas the lowest obtained by the birds fed diet $1(1448,1410) \mathrm{g}$ respectively $1^{\text {st }}, 2^{\text {nd }}, 3^{\text {rd }}, 4^{\text {th }}$ and $5^{\text {th }}$ weeks of the experimental period showed the same pattern, while there were no significant differences in live weight and weight gain of bird fed diets 2 and 4 .

Table2. Influence of different levels of crude protein and metabolizable energy on body weight/g 1 to 5 weeks of age's \pm SE

\begin{tabular}{|l|l|l|l|l|l|}
\hline \multirow{2}{*}{ Treatment } & \multicolumn{5}{|c|}{ Bird age (week) } \\
\cline { 2 - 6 } & 1 & 2 & 3 & 4 & 5 \\
\hline T1 & $113 \pm 2.2 \mathrm{~b}$ & $261.8 \pm 4.3 \mathrm{~b}$ & $645 \pm 16.2 \mathrm{~b}$ & $1028.6 \pm 25.3 \mathrm{~b}$ & $1448 \pm 28.1 \mathrm{c}$ \\
\hline T2 & $116.3 \pm 2.5 \mathrm{~b}$ & $281.7 \pm 13.7 \mathrm{~b}$ & $670.3 \pm 18.2 \mathrm{~b}$ & $1065 \pm 22.2 \mathrm{~b}$ & $1555 \pm 25.6 \mathrm{~b}$ \\
\hline T3 & $128 \pm 3.8 \mathrm{a}$ & $323.5 \pm 4.2 \mathrm{a}$ & $715 \pm 8.5 \mathrm{a}$ & $1163 \pm 14.8 \mathrm{a}$ & $1723 \pm 19.5 \mathrm{a}$ \\
\hline T4 & $131 \pm 2.4 \mathrm{a}$ & $313.8 \pm 7.4 \mathrm{a}$ & $650.3 \pm 9.6 \mathrm{~b}$ & $1050.6 \pm 16.4 \mathrm{~b}$ & $1505 \pm 22.4 \mathrm{bc}$ \\
\hline significant & $*$ & $*$ & $*$ & $*$ & $*$ \\
\hline
\end{tabular}

*Values within the same column with different letters are significantly $(\mathrm{p}<0.05)$

Table 3. Influence of different levels of crude protein and metabolizable energy on weight gain/g 1 to 5 weeks of age's \pm SE

\begin{tabular}{|l|c|c|c|c|c|c|}
\hline \multirow{2}{*}{ Treatment } & \multicolumn{5}{|c|}{ Bird age (day) } & Cumulative \\
\cline { 2 - 7 } & $1-7$ & $8-14$ & $15-21$ & $22-28$ & $29-35$ & $1-35$ \\
\hline T1 & $75 \pm 2.2 \mathrm{~b}$ & $148.8 \pm 5.1 \mathrm{~b}$ & $383.2 \pm 8.9 \mathrm{a}$ & $383.6 \pm 11.5 \mathrm{~b}$ & $419.4 \pm 19.7 \mathrm{c}$ & $1410 \pm 28.1 \mathrm{c}$ \\
\hline T2 & $78.3 \pm 2.5 \mathrm{~b}$ & $165.4 \pm 12.1 \mathrm{~b}$ & $388.6 \pm 6.5 \mathrm{a}$ & $394 \pm 13.3 \mathrm{~b}$ & $490 \pm 21.6 \mathrm{~b}$ & $1517 \pm 25.6 \mathrm{~b}$ \\
\hline T3 & $90 \pm 3.8 \mathrm{a}$ & $195.5 \pm 5.4 \mathrm{a}$ & $391.5 \pm 7.4 \mathrm{a}$ & $448 \pm 9.3 \mathrm{a}$ & $560 \pm 16.8 \mathrm{a}$ & $1685 \pm 19.5 \mathrm{a}$ \\
\hline T4 & $93.5 \pm 2.4 \mathrm{a}$ & $182.3 \pm 8.3 \mathrm{a}$ & $336.5 \pm 9.2 \mathrm{~b}$ & $400.3 \pm 12.9 \mathrm{~b}$ & $454.4 \pm 17.9 \mathrm{bc}$ & $1467 \pm 22.4 \mathrm{bc}$ \\
\hline significant & $*$ & $*$ & $*$ & $*$ & $*$ & $*$ \\
\hline
\end{tabular}

*Values within the same column with different letters are significantly $(\mathrm{p}<0.05)$ 
It can be seen in table 4 that there were no significant differences in the mean total feed consumption of the experimental birds at $1^{\text {st }}$ and $2^{\text {nd }}$ weeks. The dietary treatment 4 had significant $(p<0.05)$ decrease effects on the $3^{\text {rd }}, 4^{\text {th }}, 5^{\text {th }}$ and accumulated feed $(446,580,721$ and 2013) $\mathrm{g}$ respectively consumption as compared with treatments 1,2 and 3.

Table 4. Influence of different levels of crude protein and metabolizable energy on feed consumption (g/bird) 1 to 5 weeks of age's \pm SE

\begin{tabular}{|l|c|c|c|c|c|c|}
\hline \multirow{2}{*}{ Treatment } & \multicolumn{5}{|c|}{ Bird age (week) } & Cumulative \\
\cline { 2 - 7 } & $0-1$ & $1-2$ & $2-3$ & $3-4$ & $4-5$ & $0-5$ \\
\hline T1 & $88.75 \pm 4.4$ & $252.6 \pm 12.6$ & $550.6 \pm 14.7 \mathrm{a}$ & $655 \pm 7.3 \mathrm{a}$ & $822 \pm 18.8 \mathrm{a}$ & $2308.9 \pm 24.2 \mathrm{a}$ \\
\hline T2 & $92.5 \pm 2.1$ & $244.9 \pm 13.5$ & $519.6 \pm 15.2 \mathrm{a}$ & $649.6 \pm 9.1 \mathrm{a}$ & $842 \pm 15.9 \mathrm{a}$ & $2288.6 \pm 29.8 \mathrm{a}$ \\
\hline T3 & $96.6 \pm 3.7$ & $257.6 \pm 12.8$ & $528.3 \pm 16.5 \mathrm{a}$ & $666 \pm 8.4 \mathrm{a}$ & $858 \pm 17.8 \mathrm{a}$ & $2346.5 \pm 27.8 \mathrm{a}$ \\
\hline T4 & $95.4 \pm 4.4$ & $231.3 \pm 13.7$ & $446 \pm 15.9 \mathrm{~b}$ & $580 \pm 10.9 \mathrm{~b}$ & $721 \pm 19.4 \mathrm{~b}$ & $2013.7 \pm 26.6 \mathrm{~b}$ \\
\hline significant & N.S & N.S & $*$ & $*$ & $*$ & $*$ \\
\hline
\end{tabular}

*Values within the same column with different letters are significantly $(\mathrm{p}<0.05)$

N.S $=$ non-significant

Table (5) indicated that the experiment diets had significant $(\mathrm{p}<0.05)$ effects on weekly feed conversation ratio (FCR) during the period from $1^{\text {st }}, 2^{\text {nd }}, 3^{\text {rd }}, 4^{\text {th }}, 5^{\text {th }}$ and the accumulation feed conversion ratio, during these period the birds fed diets 1 showed significant increase in FCR, whereas the birds feed on diets 3 and 4 showed significant decrease in FCR.

Table 5. Influence of different levels of crude protein and metabolizable energy on feed conversation ratio ( $\mathrm{g}$ feed /g weight gain) 1 to 5 weeks of age's \pm SE

\begin{tabular}{|l|c|c|c|c|c|c|}
\hline \multirow{2}{*}{ Treatment } & \multicolumn{5}{|c|}{ Bird age (week) } & Cumulative \\
\cline { 2 - 7 } & $0-1$ & $1-2$ & $2-3$ & $3-4$ & $4-5$ & $0-5$ \\
\hline T1 & $1.18 \pm 0.01 \mathrm{a}$ & $1.69 \pm 0.03 \mathrm{a}$ & $1.43 \pm 0.02 \mathrm{a}$ & $1.7 \pm 0.04 \mathrm{a}$ & $1.96 \pm 0.03 \mathrm{a}$ & $1.64 \pm 0.03 \mathrm{a}$ \\
\hline T2 & $1.18 \pm 0.01 \mathrm{a}$ & $1.48 \pm 0.02 \mathrm{~b}$ & $1.34 \pm 0.03 \mathrm{~b}$ & $1.65 \pm 0.03 \mathrm{a}$ & $1.71 \pm 0.04 \mathrm{~b}$ & $1.51 \pm 0.03 \mathrm{~b}$ \\
\hline T3 & $1.07 \pm 0.02 \mathrm{~b}$ & $1.31 \pm 0.04 \mathrm{c}$ & $1.34 \pm 0.04 \mathrm{~b}$ & $1.48 \pm 0.02 \mathrm{~b}$ & $1.53 \pm 0.03 \mathrm{c}$ & $1.39 \pm 0.03 \mathrm{c}$ \\
\hline T4 & $1.02 \pm 0.03 \mathrm{~b}$ & $1.27 \pm 0.04 \mathrm{c}$ & $1.32 \pm 0.02 \mathrm{~b}$ & $1.45 \pm 0.02 \mathrm{~b}$ & $1.58 \pm 0.02 \mathrm{c}$ & $1.37 \pm 0.02 \mathrm{c}$ \\
\hline significant & $*$ & $*$ & $*$ & $*$ & $*$ & $*$ \\
\hline
\end{tabular}

*Values within the same column with different letters are significantly $(\mathrm{p}<0.05)$

The weekly nutrients intake from M.E and crude protein of the experimental birds followed the same pattern of the total feed intake (table 6,7). It can be seen that diet 3 had the highest statistically significant $(p<0.05)$ effects consumption of the total M.E $7635 \mathrm{Kcal}$ and crud protein $516.21 \mathrm{~g}$ intake during all weeks experimental period. The birds fed diet 1 and 4 showed the lowest M.E $(6815,6876.2)$ Kcal and crude protein intake $(463.24,466.08)$ g. the M.E and crude protein intake by the birds fed diets was slightly better over by the birds fed diet 1 and 2 but less than diet 3

Table 6. Influence of different levels of crude protein and metabolizable energy on total crude protein consumption (g/bird) 1 to 5 weeks of age's \pm SE

\begin{tabular}{|l|c|c|c|c|c|c|}
\hline \multirow{2}{*}{ Treatment } & \multicolumn{5}{|c|}{ Bird age (week) } & Cumulative \\
\cline { 2 - 7 } & $0-1$ & $1-2$ & $2-3$ & $3-4$ & $4-5$ & $0-5$ \\
\hline T1 & $19.53 \pm 0.3 \mathrm{~b}$ & $55.59 \pm 1.7 \mathrm{~b}$ & $121.18 \pm 2.0 \mathrm{~b}$ & $118.38 \pm 3.5 \mathrm{~b}$ & $148.56 \pm 4.7 \mathrm{c}$ & $463.24 \pm 11.4 \mathrm{c}$ \\
\hline T2 & $21.27 \pm 0.7 \mathrm{a}$ & $56.33 \pm 1.5 \mathrm{~b}$ & $119.5 \pm 2.2 \mathrm{~b}$ & $123.81 \pm 3.3 \mathrm{~b}$ & $160.48 \pm 4.2 \mathrm{~b}$ & $481.39 \pm 13.8 \mathrm{~b}$ \\
\hline T3 & $23.17 \pm 0.9 \mathrm{a}$ & $61.79 \pm 1.3 \mathrm{a}$ & $126.72 \pm 2.2 \mathrm{a}$ & $133.35 \pm 3.4 \mathrm{a}$ & $171.18 \pm 4.9 \mathrm{a}$ & $516.21 \pm 14.9 \mathrm{a}$ \\
\hline T4 & $23.83 \pm 1.4 \mathrm{a}$ & $57.78 \pm 1.9 .3 \mathrm{~b}$ & $111.42 \pm 2.3 \mathrm{c}$ & $121.73 \pm 3.2 \mathrm{~b}$ & $151.32 \pm 3.9 \mathrm{c}$ & $466.08 \pm 14.3 \mathrm{bc}$ \\
\hline significant & $*$ & $*$ & $*$ & $*$ & $*$ & $*$ \\
\hline
\end{tabular}

*Values within the same column with different letters are significantly $(\mathrm{p}<0.05)$

N.S= non-significant

Table 7. Influence of different levels of crude protein and metabolizable energy on total metabolizable energy consumption (g/bird) 1 to 5 weeks of age's \pm SE

\begin{tabular}{|l|c|c|c|c|c|c|}
\hline \multirow{2}{*}{ Treatment } & \multicolumn{5}{|c|}{ Bird age (week) } & Cumulative \\
\cline { 2 - 7 } & $0-1$ & $1-2$ & $2-3$ & $3-4$ & $4-5$ & $0-5$ \\
\hline T1 & $254.2 \pm 6.3 \mathrm{c}$ & $723.4 \pm 13.9 \mathrm{~b}$ & $1576 \pm 19.9 \mathrm{~b}$ & $1890 \pm 42.6 \mathrm{~b}$ & $2372 \pm 65.7 \mathrm{c}$ & $6815.4 \pm 105.5 \mathrm{c}$ \\
\hline T2 & $276.6 \pm 5.8 \mathrm{~b}$ & $732.3 \pm 12.6 \mathrm{~b}$ & $1553 \pm 22.5 \mathrm{~b}$ & $1975 \pm 45.3 \mathrm{~b}$ & $2560 \pm 62.1 \mathrm{~b}$ & $7096.9 \pm 101.9 \mathrm{~b}$ \\
\hline T3 & $301.4 \pm 4.1 \mathrm{a}$ & $803.7 \pm 10.5 \mathrm{a}$ & $1648 \pm 20.3 \mathrm{a}$ & $2133 \pm 33.8 \mathrm{a}$ & $2749 \pm 55.9 \mathrm{a}$ & $7635.1 \pm 110.3 \mathrm{a}$ \\
\hline T4 & $309.8 \pm 6.4 \mathrm{a}$ & $751 \pm 16.8 \mathrm{~b}$ & $1448 \pm 25.1 \mathrm{c}$ & $1947 \pm 39.9 \mathrm{~b}$ & $2420 \pm 58.5 \mathrm{c}$ & $6876.2 \pm 96.3 \mathrm{c}$ \\
\hline significant & $*$ & $*$ & $*$ & $*$ & $*$ & $*$ \\
\hline
\end{tabular}

*Values within the same column with different letters are significantly $(\mathrm{p}<0.05)$

N.S= non-significant 
The data of same carcass parameters is summarized in table 8 . The highest dressing percentage, were obtained by the treatment of broiler chickens fed treatment three while the gizzard, proventriculus and abdominal fat percentage were the lower as compared with treatments 1,2 and 4 . A significant $(\mathrm{p}<0.05)$ percentage was obtained in production index was noticed in T3 (338.570 and the lowest in T1 (246.71).

Table 8. Influence of different levels of crude protein and metabolizable energy on some carcass parameters at 5 weeks of age's \pm SE

\begin{tabular}{|l|l|l|l|l|l|}
\hline parameter & T1 & T2 & T3 & T4 & significant \\
\hline Dressed weight (\%) & $73.3 \pm 0.21 \mathrm{c}$ & $74.4 \pm 0.13 \mathrm{~b}$ & $75.5 \pm 0.32 \mathrm{a}$ & $73.2 \pm 0.11 \mathrm{c}$ & $*$ \\
\hline Thigh (\%) & $29.5 \pm 0.55$ & $29.1 \pm 0.88$ & $30.6 \pm 0.71$ & $29.5 \pm 0.59$ & N.S \\
\hline Breast (\%) & $28.2 \pm 0.93$ & $30.2 \pm 0.82$ & $29.9 \pm 0.91$ & $30.7 \pm 0.97$ & N.S \\
\hline Liver (\%) & $3.25 \pm 0.23$ & $3.07 \pm 0.12$ & $3.16 \pm 0.16$ & $3.28 \pm 0.26$ & N.S \\
\hline Heart (\%) & $0.65 \pm 0.03$ & $0.68 \pm 0.04$ & $0.67 \pm 0.01$ & $0.65 \pm 0.02$ & N.S \\
\hline Gizzard (\%) & $1.35 \pm 0.05 \mathrm{a}$ & $1.23 \pm 0.07 \mathrm{a}$ & $0.99 \pm 0.08 \mathrm{~b}$ & $1.04 \pm 0.02 \mathrm{~b}$ & $*$ \\
\hline Proventriculus (\%) & $0.52 \pm 0.03 \mathrm{a}$ & $0.55 \pm 0.02 \mathrm{a}$ & $0.44 \pm 0.02 \mathrm{~b}$ & $0.53 \pm 0.04 \mathrm{a}$ & $*$ \\
\hline Abdominal fat (\%) & $1.26 \pm 0.09 \mathrm{~b}$ & $1.28 \pm 0.06 \mathrm{~b}$ & $1.27 \pm 0.07 \mathrm{~b}$ & $1.44 \pm 0.05 \mathrm{a}$ & $*$ \\
\hline
\end{tabular}

*Values within the same row with different letters are significantly $(\mathrm{p}<0.05)$

N.S= non-significant

Table 9. Influence of different levels of crude protein and metabolizable energy on production index AT 5 weeks of age's $\pm \mathrm{SE}$

\begin{tabular}{|c|c|c|}
\hline treatment & production index & significant \\
\hline T1 & $246.71 \pm 20.22 \mathrm{c}$ & $*$ \\
\hline T2 & $287.75 \pm 18.65 \mathrm{~b}$ & $*$ \\
\hline T3 & $338.57 \pm 21.11 \mathrm{a}$ & $*$ \\
\hline T4 & $300.05 \pm 11.23 \mathrm{~b}$ \\
\hline
\end{tabular}

*Values within the same column with different letters are significantly $(\mathrm{p}<0.05)$

\section{Discussion}

Ross guide 2014 which recommended that $23 \%$ C.P and $2990 \mathrm{Kcal} / \mathrm{kg}$ at the starter and $19 \%$ C.P and $3050 \mathrm{Kcal} / \mathrm{kg}$ diet at the finisher were not enough to meet the Ross broiler chicken in basrah environment condition

In this study the ratio between energy and protein values of each treatment diets was the same 130 to the starter and 160 to the finisher phase, this range of energy and crude protein ratio was not enough to meet the best requirement to the broiler performance broiler are fed different metabolizable energy and protein levels (afatab et al., 2006). The lower body weight and weight gain were showed in treatments 1,2 and 4 as compared with treatment 3 . Results in treatment 4 indicated that excess high protein and metabolizable energy content to improved native chicken has no advantage, this excess in this treatment has been reported to be dissipated after consumption usually in the order of protein (NRC, 1994; Gous and Morris, 2005).

This means there is a threshold above and below $(20,3200)$ which the crude protein and metabolizable energy value us a nutrient is not justifiable ( $\mathrm{Si}$ et al., 2001) hence no positive result is expected in terms of growth and other performance indices. It has been shown that treatments 3 showed a high performance, this may be because of better diet digestibility and benefits level of energy and protein in this diet (Moravej et al., 2006). In chicks fed with high energy level fed intake decrease, it could be attributed to poor digestion in broiler chickens (Lee and summers, 2001).

Danisman and Gons (2013) who also showed that broiler fed with high energy and protein had reduced feed consumption and improved feed conversion ratio. The abdominal fat deposition percentage increased in treatment 4 which agreed with result of Swennen et al. (2006). This result was in variance with the work of Sizemore and Siegel (1993) who reported no effect of dietary fat concentration on abdominal fat in broiler of constant calorie: protein ratio. Increasing abdominal fat content is a direct reflection of the energy value of treatment 4.

Dressing percentage in treatment 3 was influenced by weight of these chickens, as there is a positive relationship between body weight and dressing percentage (AL-Fayadh and Naji, 1989).

\section{Conclusion}

It can be concluded that with adequate balance of calorie and protein $3120 \mathrm{Kcal}$ and $24 \%$ C.P $/ \mathrm{kg}$ at starter; 3204 Kcal and $20 \%$ C.P $/ \mathrm{kg}$ diet at finisher Ross diet at basrah region to be fed to improve the performance of the broiler chickens

\section{References}

Aftab. U., Ashraf, M. and Jiang, Z. (2006), "Low protein diets for broilers”, World Poultry. Sci. J., 62: 688 - 701. 
AL-Fayadh, H. A. and Naji, S. A. H. (1989), "Poultry by product technology”, Education and Scientific Research, Baghdad University.

Dairo, F. A. S., Adesehinwa, A. O. K., Oluwasola, T. A. and Oluyemi. J. A. (2010), "High and low dietary energy and protein levels for broiler chickens",African Journal of Agricultural Research Vol. 5(15): 2030-2038.

Danisman, R. and Gous, R. (2013), "Effect of dietary protein on performance of four broiler strains and on the allometric relationships between carcass portions and body protein", S. Afr. J. Anim. Sci 43(1): 25-37.

Durunna, C.S., Udedibie, A.B.I. and Uchegbu, M.C. (2005), "Effect of dietary inclusion of Anthonata macrophyla meal on the performance of broiler starter chicks", Nigerian Journal of Animal Production, 32(2): 268-273.

Food and Agriculture Organization of the United Nations (FAO). (2003), "Animal production and health paper", Good practices in planning and management of integrated commercial poultry production in South Asia. 97 page

Gous, R. M. and Morris, T. R. (2005), "Nutritional interventions in alleviating the effects of high temperatures in broiler production", World Poultry Sc. J., 61: 463-475.

Kamran, Z., Aslam Mirza, M., Ahsan-ul-Haq and Mahmood, S. (2004), "Effect of decreasing dietary protein levels with optimum amino acids profile on the performance of broilers", Pakistan Veterinary Journal 24(4): 268273.

Moravej, H., Khazali, H., Shivazad, M. and Mehrabani-Yeganeh, H. (2006), "Plasma Concentrations of Thyroid Hormone and Growth Hormone in Lohmann Male Broilers Fed on Different Dietary Energy and Protein Levels",International Journal of Poultry Science 5 (5): 457-462.

Naji, S. A. H. (2006), "Commercial broiler production manual”, Brochure no. (12).

National Research Council, (NRC). (1994), "Nutrient Requirements of Poultry”, 9th Revised Ed. National Academy Press, Washington, DC.

Ojewola, G. S. and Longe, O. G. (1999), "Protein and energy in broiler starter diets: Effect on growth performance and nutrient utilization", Nig. J. Anim. Prod., 26: 23-28.

Olomu, J. M. and Offiong, S. A. (1980), "The effect of different protein and energy levels and time of change from starter to finisher ration on the performance of broiler chickens in the tropics", Poult. Sci., 59: 828-835.

Rahimi, G. and Hassanzadeh, M. (2007), "Effects of Different Protein and Energy Contents of the Diet on Growth Performance and Hormonal Parameters in Two Commercial Broiler Strains", International Journal of Poultry Science 6 (3): 195-200.

Si, J., Fritts, C. A., Burnham, D. J. and Waldroup, P.W. (2001), "Relationship of dietary lysine level to the concentration of all essential amino acids in broiler diets. Poult", Sci., 80: 1472-1479.

Sizemore, F. G. and Siegel, H. S. (1993), "Growth, feed conversion, and carcass composition in females of four broiler crosses fed starter diets with different energy levels and energy to CP ratios", Poult. Sci. 72:22162228

SPSS. (2009). SPSS. (2009), "Statistical Package of Soc”, Sci., Ver.18. Appl. Guide. Chicago, Illinois: SPSS Inc. Swennen, Q., Janssens, G. P. J., Collin, A., Bihan-Duval, E. L., Verbeke, K., Decuypere, E. and Buyse, J. (2006), "Diet-induced thermogenesis and glucose oxidation in broiler chickens: Influence of genotype and diet composition", Poult. Sci., 85: 731-742. 